\title{
Transdermal Delivery of Ondansetron Hydrochloride in the management of Hyperemesis Gravidarum
}

\author{
Snigdha Bhardwaj ${ }^{1 *}$, Sonam Bhatia ${ }^{1}$, Shaminder Singh ${ }^{2}$ \\ ${ }^{1}$ Department of Pharmaceutical Sciences, Shalom Institute of Health \& Allied Sciences, \\ Sam Higginbottom University of Agriculture, Technology \& Sciences, Prayagraj, U.P, India \\ E-mail ID: snigs.16@gmail.com, sonam.bhatia@shiats.edu.in \\ ${ }^{2}$ Regional Centre for Biotechnology, NCR Biotech Science Cluster, 3rd Milestone, \\ Faridabad-Gurugram Expressway, Faridabad - 121 001, Haryana, India. \\ E-mail ID: shaminder2@gmail.com
}

\begin{abstract}
Transdermal route has always been a route of choice for those drugs having limitations through oral route. Transdermal delivery of Ondansetron Hydrochloride $(\mathrm{HCl})$ is one of the potential strategies, capable of maximizing the drug performance in patients with Hyperemesis Gravidarum facing issues with oral drug delivery. Current study focused on the development of matrix transdermal patches of Ondansetron HCl using solvent casting method with combination of different polymers and eugenol as penetration enhancer followed by physical characterization for various parameters such as weight variation, folding endurance, moisture content, moisture uptake, drug content, tensile strength, elongation break test, FT-IR studies, in-vitro percent drug release, stability studies. The result suggested that formulation $\mathrm{F} 3$ exhibited optimum results in respect to physical evaluation and in-vitro drug release exhibited release in concentration independent manner (62.2 $1.3 \%$ upto $8 \mathrm{hrs})$. All formulations followed zero-order kinetics and Higuchi's model values showed 'diffusion' as predominant release mechanism. FT-IR analysis revealed that there are no potential chemical interactions between the drug and the polymers. Stability studies revealed promising result and the formulation (F3) was found to be stable at $40 \pm 2^{\circ} \mathrm{C}$ and $75 \pm 5 \% \mathrm{RH}$. The study indicated that transdermal delivery of Ondansetron $\mathrm{HCl}$ is a suitable way to increase therapeutic effectiveness.
\end{abstract}

Keywords: Diffusion, hyperemesis gravidarum, in-vitro drug release, penetration enhancer, stability, transdermal patch

\section{Introduction}

Transdermal drug delivery system or self contained discrete dosage forms that are intended to deliver the drugs through skin into systemic circulation at controlled rate $(1,2)$. Ondansetron Hydrochloride $(\mathrm{HCl})$, serotonin (5HT3 receptor) antagonist, is indicated in the management of post-operative and chemotherapeutics induced nausea and vomiting (3). It is also considered safe in pregnant women (1-10\%) suffering with unexplained severe morning sickness in early stage of pregnancy, the condition is called 'Hyperemesis Gravidarum'. In the literature, various reports have been published related to the management of Hyperemesis Gravidarum condition $(4,5)$. The low oral bioavailability $(<60 \%)$ and rapid elimination rate (t1/2- 3 to $4 \mathrm{hrs}$ ) of Ondansetron $\mathrm{HCl}$ evokes the need to develop alternative approach. Various factors such as poor bioavailability, low molecular weight, shorter half life, and good skin penetration makes the ondansetron hydrochloride an ideal drug for transdermal delivery $(6,7,8)$. Transdermal drug delivery system has many advantages over oral drug delivery system as it avoids hepatic first pass metabolism, facilitates easy termination of therapy (in case of undesired effect occurs), better patient compliance, better penetration through skin of variety of drugs with the use of penetration enhancer $(9,10,11)$. The key highlight points of transdermal delivery of Ondansetron $\mathrm{HCl}$ over the oral route are its reduced frequency of administration, sustained drug release time, constant and prolonged drug level maintained in plasma, reduced inter and intra patient variability and improved patient compliance in the long term therapy. All these factors contribute towards designing an efficient way to achieve safe drug delivery via transdermal route in patients with hyperemesis gravidarum in order to avoid side effect caused by oral administration in such patients that may lead to discontinuation of the treatment regime $(12,13)$. The current investigation aimed at the development and characterization of Ondansetron $\mathrm{HCl}$ Transdermal delivery system to maximize the drug therapy (bioavailability) in contrast to oral delivery. When compared with other studies done on Ondansetron $\mathrm{HCl}$, present study offers several advantages such as formulation of patch with simple and feasible method, using combination of polymers that are good film formers, economic and widely available. 


\section{A. Materials}

Ondansetron $\mathrm{HCl}$ was supplied as a gift sample from Lupin Laboratory Park, Aurangabad, India. All other chemicals were purchased from Sigma-Aldrich, New Delhi, India. All other polymers and solvents used were of pharmaceutical and analytical grades respectively.

\section{B. Preparation of Transdermal Patches}

Transdermal patches of Ondansetron $\mathrm{HCl}$ were prepared by solvent casting method using various polymers such as Polyvinyl Alcohol (PVA), Hydroxypropyle Methyl cellulose (HPMC) K4M, Polyvinylpyrrolidone (PVP) K30 and Eudragit RL100. The calculated amounts of all polymers were mixed in methanol. After complete solubilization of polymers, a measured quantity of Ondansetron $\mathrm{HCl}$ was then mixed in polymeric solution followed by addition of eugenol (penetration enhancer). The slurry was thoroughly mixed with concurrent agitation to get semisolid consistency. At that point the arrangement was subjected to sonication to remove the air bubbles. After this, the content was transferred onto a glass surface utilizing ' $O$ ' shape ring (4cm in diameter) which was permitted to dry at room temperature for solvent evaporation. After $12 \mathrm{hrs}$, the dried patches were taken out and stored between sheets of wax in desiccators (14-15). The composition of patches is given in Table 1 .

Table 1: Formulation of transdermal patches of Ondansetron Hydrochloride

\begin{tabular}{|l|l|l|l|l|l|l|}
\hline \multirow{2}{*}{ Ingredients } & \multicolumn{7}{c|}{ Formulation Code } \\
\cline { 2 - 8 } & F1 & F2 & F3 & F4 & F5 & F6 \\
\hline Ondansetron Hydrochloride (mg) & 10 & 10 & 10 & 10 & 10 & 10 \\
\hline Methanol (ml) & 10 & 10 & 10 & 10 & 10 & 10 \\
\hline PVA (\%) & 10 & 5 & 5 & - & - & - \\
\hline EC (\%) & 5 & 10 & 5 & 10 & 5 & 5 \\
\hline PVP (\%) & 5 & 5 & 10 & 5 & 10 & 5 \\
\hline HPMC- K4M (\%) & - & - & - & 5 & 5 & 10 \\
\hline
\end{tabular}

*Note: Each transdermal patch contains 1\% eugenol as penetration enhancer, 25\% Polyethylene Glycol (PEG 4000) as plasticizer. EC-Ethyl Cellulose, PVA- Polyvinyl Alcohol, PVP- Polyvinyl pyrrolidone, HPMC- K4M Hydroxypropylmethyl cellulose-K4M.

\section{Preparation of Standard Curve of Ondansetron HCl}

Ondansetron HCL $(1 \mathrm{mg})$ was dissolved in phosphate buffer $(\mathrm{pH}=7.4)$ and volume was made up to $100 \mathrm{ml}$ in volumetric jar. This stock solution $(100 \mu \mathrm{g} / \mathrm{ml})$ was further used to make dilutions of 2, 4, 6, 8, $10 \mu \mathrm{g} / \mathrm{ml}$. Absorbance of each and every sample was estimated at $310 \mathrm{~nm}$ utilizing Shimadzu UV-1700 UV/VIS twofold shaft spectrophotometer and phosphate buffer $(\mathrm{pH}=7.4)$ was used as reference standard. The standard graph was plotted against concentration and slope was calculated (16).

\section{Evaluation of Transdermal Patch}

\section{a. Physical Characterization}

The formulated transdermal patches were visually observed for surface smoothness and clarity. The thickness of the patches was evaluated at three different points using screw gauge. For each formulation, the study was done in triplicate. In weight variation study, three discs of $2 \times 2 \mathrm{~cm}^{2}$ were cut and weight using digital balance. The folding endurance was measured manually for prepared transdermal patches. A strip of $4 \times 2 \mathrm{~cm}^{2}$ size was cut evenly and folded repeatedly at the same point of strip until it broke. The drug content uniformity was performed by taking patch strip of $3.83 \mathrm{~cm}^{2}$ which was dissolved in phosphate buffer of $\mathrm{pH} 7.4$. Then chloroform and water were added to the mixture to make polymer soluble and remaining volume was made up with phosphate buffer upto $100 \mathrm{~mL}$. Further dilutions were made and the absorbance of solution was taken at $310 \mathrm{~nm}$ followed by calculation of overall drug content present in formulation (17-19).

\section{b. Moisture content $(\%)$}

The patches were weighed freely and kept in a dessicator containing calcium chloride at $37^{\circ} \mathrm{C}$ for 24 hrs. The weight of patches was noted till constant weight observed (20,21). The percent of moisture content (MC) was calculated using a equation 1 given below:

$$
\% \mathrm{MC}=\frac{(\mathrm{X}-\mathrm{Y})}{\mathrm{Y}} \times 100
$$

Where, $\mathrm{X}=$ initial weight, $\mathrm{Y}=$ final weight 


\section{c. Moisture uptake (\%)}

Percent moisture uptake (MU) test was performed to identify physical integrity and stability of the prepared patches at high humidity. This can be measured by placing patch in dessicator containing $200 \mathrm{ml}$ of potassium chloride saturated solution that suppose to develop humidity at $84 \% \mathrm{RH}$ in dessicator. After 3 days, the patched were taken out and subjected to weight measurement $(20,21)$. The percent moisture uptake can be calculated by equation 2 given below:

$$
\% \mathrm{MU}=\frac{(\mathrm{X}-\mathrm{Y})}{\mathrm{Y}} \times 100
$$

Where, $\mathrm{X}=$ initial weight, $\mathrm{Y}=$ final weight

\section{d. Tensile strength}

The tensile strength of the matrix type transdermal patches of Ondansetron $\mathrm{HCl}$ was measured by microprocessor force gauge attached with motor equipped with stand and cell. The smooth and clear patch strip of $20 \mathrm{~mm}$ in size were cut and placed between two clamps kept at a distance of $2 \mathrm{~cm}$. The assembly of clamps is set in such a way that it should not cause any damage to the placed patch strip during experimentation. The lower clamp was set at fixed position while the upper clamp was allowed to move at speed of $2 \mathrm{~mm} / \mathrm{sec}$ till the patch broke. The point of patch break just after elongation was noted down and tensile strength of patch was calculated using equation 3 given below: (22)

$$
\text { Tensile Strength }=\frac{\mathrm{Fb}}{\mathrm{A}}
$$

Where, $\mathrm{Fb}=$ Force at break $(\mathrm{Kg}), \mathrm{A}=$ Initial Cross sectional area of sample $(\mathrm{mm} 2)$

\section{e. Percentage Elongation Break Test}

The percent elongation break for all transdermal patches was determined by observing the length just before the break point using the equation 4 given below: (23)

$$
\% \text { Elongation }=\frac{\left(\mathrm{L}_{1}-\underline{L}_{2}\right)}{\mathrm{L}_{2}} \times 100
$$

Where $L_{1}$ is the final length of each strip, and $L_{2}$ is the initial length of each strip.

\section{f. In-vitro Permeation Studies}

In-vitro drug release or permeation studies were conducted using Franz diffusion cell with a receptor compartment capacity of $60 \mathrm{~mL}$. The drug content, from matrix type transdermal patch, was determined using cellulose acetate membrane with $0.45 \mu$ pore size. In the diffusion cell, the formulated transdermal patch was placed on the cellulose acetate membrane, covered with aluminum foil and mounted between donor and receptor compartment. After the assembly, the receptor compartment was filled with phosphate buffer (pH 7.4). The whole set up was fixed on hot plate magnetic stirrer maintaining the temperature $32 \pm 0.5^{\circ} \mathrm{C}$ of the receptor compartment followed by continuous and constant stirring using magnetic beads. The samples collection was done at different time intervals maintaining sink conditions. The drug content in sample was analyzed by using UV-VIS spectrophotometer $(24,25)$.

\section{g. Drug Release Kinetics of Ondansetron HCI Transdermal Patch}

To investigate the mode of drug release from Ibuprofen loaded niosomes, the release data were fitted with the following mathematical models (26-28).

(i) Zero-order kinetics equation (5):

$$
\mathrm{Qt}=\mathrm{k}_{0} . \mathrm{t}
$$

Where Qt is the amount of drug released at time $t, \mathrm{k}_{0}$ is the zero-order release rate constant, $\mathrm{t}$ is the time

(ii) First-order kinetics equation (6):

$$
\text { In } \mathrm{Qt}=\text { In } \mathrm{Q}_{0}-\mathrm{k} 1 . \mathrm{t}
$$

Where, Qt is the amount of drug released at time $t, \mathrm{Q}_{0}$ is the initial amount of drug in the solution, $\mathrm{k}_{1}$ is the firstorder release rate constant

(iii) Higuchi model kinetics equation (7):

$$
\mathrm{Qt}=\mathrm{kH} . \mathrm{t} 1 / 2
$$

Where Qt is the amount of drug released at time $\mathrm{t}, \mathrm{k}_{\mathrm{H}}$ is the Higuchi release rate constant 


\section{h. Drug- Excipient Interaction study by FT-IR Spectrometry}

For interaction studies, FTIR spectrometry was performed on FTIR Model 8400-S Spectrometer, Shimadzu, Japan. Test samples were ground altogether with $\mathrm{KBr}$ control in mortar and pestle, in a weight proportion of 1:100 and after that mixed the blend followed by making of pellets in pellet press. After this, the pellet was kept in the holder and transmittance was measured in the frequency of wavelength ranged 400 and $2000 \mathrm{~cm}-1$ at a determination of $2 \mathrm{~cm}-1$ and sweep speed of $2 \mathrm{~mm} / \mathrm{sec}$. IR spectra of both pure drug and physical blend was then taken out and observed for any interactions of excipients with pure drug (29).

\section{i. Stability Studies}

A stability study was performed as per ICH guidelines to observe the stability of Ondansetron $\mathrm{HCl}$ in $\mathrm{F} 3$ formulation. The samples, in triplicate, were packed in polyethylene coated aluminum sheet and kept inside stability chamber at $40 \pm 2^{\circ} \mathrm{C}$ and $75 \pm 5 \% \mathrm{RH}$ for three months. After three months samples were collected and evaluated for drug content and percent drug release. Further, statistical analysis was done using paired t-test to calculate statistical difference at 0.05 level of significance followed by calculating similarity index of percent drug release of $\mathrm{F} 3$ formulation before and after storage period (30).

\section{RESULTS}

\section{A. Standard Curve of Ondansetron Hydrochloride}

From already prepared stock solution, five dilutions were made by using phosphate buffer solution of $\mathrm{pH} 7.4$ which has ultimate concentrations of $2 \mu \mathrm{g} / \mathrm{ml}, 4 \mu \mathrm{g} / \mathrm{ml}, 6 \mu \mathrm{g} / \mathrm{ml}, 8 \mu \mathrm{g} / \mathrm{ml}$ and $10 \mu \mathrm{g} / \mathrm{ml}$. The absorbance was measured at $\lambda \max 310 \mathrm{~nm}$ by using UV-VIS spectrophotometer.

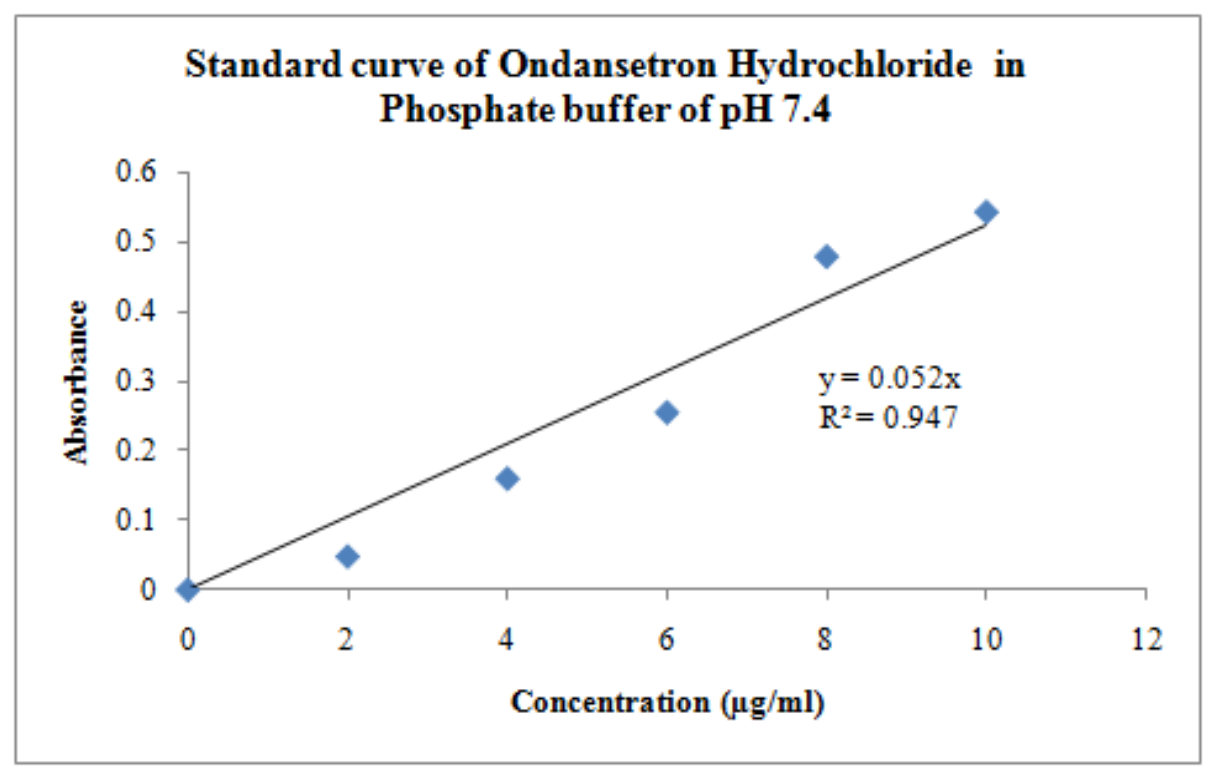

Figure 1: Standard curve of Ondansetron $\mathrm{HCl}$ in phosphate buffer of $\mathrm{pH} 7.4$ at $310 \mathrm{~nm}$

\section{B. Evaluation of Transdermal Patches}

\section{a. Physical Characterization of Transdermal Patches}

Al the transdermal patches were characterized for different physical parameters and results are shown in Table 2. In the observations, all the formulations exhibited weight variation ranging from $32 \pm 1.7$ to $38 \pm 1.8 \mathrm{mg}$. The thickness of all the formulations ranged from $18 \pm 0.9$ to $25 \pm 1$.6. The folding endurance which represents the ability of patch to withstand the stress was found in the range of $69 \pm 1.4$ to $81 \pm 1.2$. The values for moisture content $(\%)$ and moisture uptake $(\%)$ in all the formulations were found to be less than $5 \%$. The drug content for all formulations was found to be ranged from $96.28 \pm 0.45$ to $99.31 \pm 0.24 \%$. The estimation value of tensile strength of all the formulations was found between $9.12 \pm 1.4$ to $15.73 \pm 1.2$. The elongation break test (\%) values were between $7.6 \pm 1.32 \%$ to $23.8 \pm 0.92 \%$. All the results of physical characterization parameters for each formulation are given in Table 2. 
Table 2: Results of Physical Characterization of Ondansetron $\mathrm{HCl}$ Transdermal Patches

\begin{tabular}{|c|c|c|c|c|c|c|c|c|}
\hline $\begin{array}{c}\text { Formulation } \\
\text { Code }\end{array}$ & $\begin{array}{c}\text { WV } \\
\left(\mathbf{m g} / \mathbf{c m}^{\mathbf{2}}\right)\end{array}$ & $\begin{array}{c}\text { Thickness } \\
\mathbf{( m m})\end{array}$ & FE & $\begin{array}{c}\text { MC } \\
\mathbf{( \% )}\end{array}$ & MU (\%) & DC (\%) & $\begin{array}{c}\text { TS } \\
\left(\mathbf{K g} / \mathbf{m m}^{\mathbf{2}}\right)\end{array}$ & EBT (\%) \\
\hline F1 & $34 \pm 1.5$ & $22 \pm 1.1$ & $72 \pm 1.9$ & $3.7 \pm 0.98$ & $3.3 \pm 0.88$ & $96.34 \pm 0.47$ & $10.02 \pm 1.3$ & $19.13 \pm 1.1$ \\
\hline F2 & $32 \pm 1.7$ & $23 \pm 1.3$ & $76 \pm 1.7$ & $4.2 \pm 0.82$ & $2.5 \pm 0.67$ & $96.67 \pm 0.71$ & $11.89 \pm 1.6$ & $22.05 \pm 1.4$ \\
\hline F3 & $35 \pm 1.1$ & $18 \pm 0.9$ & $81 \pm 1.2$ & $2.8 \pm 0.41$ & $2.1 \pm 0.31$ & $99.31 \pm 0.24$ & $15.73 \pm 1.2$ & $23.8 \pm 0.92$ \\
\hline F4 & $34 \pm 1.4$ & $19 \pm 1.4$ & $74 \pm 2.1$ & $3.9 \pm 0.46$ & $4.2 \pm 0.46$ & $97.66 \pm 0.83$ & $9.68 \pm 1.7$ & $18.7 \pm 1.16$ \\
\hline F5 & $36 \pm 1.3$ & $20 \pm 1.1$ & $69 \pm 1.4$ & $3.5 \pm 0.67$ & $3.3 \pm 0.97$ & $96.28 \pm 0.45$ & $12.34 \pm 1.9$ & $14.9 \pm 0.98$ \\
\hline F6 & $38 \pm 1.8$ & $25 \pm 1.6$ & $75 \pm 1.3$ & $4.8 \pm 1.1$ & $4.7 \pm 1.13$ & $95.91 \pm 0.36$ & $9.12 \pm 1.4$ & $7.6 \pm 1.32$ \\
\hline
\end{tabular}

*Results were presented as mean standard deviation $(\mathrm{n}=3)$

Where, $\mathrm{WV}=$ Weight variation, $\mathrm{FE}=$ Folding Endurance, $\mathrm{MC}=$ Moisture Content, $\mathrm{MU}=$ Moisture Uptake, $\mathrm{DC}=$ Drug Content, $\mathrm{TS}=$ Tensile Strength, EBT= Elongation Break Test

\section{b. In-vitro Drug Release Studies}

The cumulative percent release of Ondansetron $\mathrm{HCl}$ from all the transdermal patches is given in Table 3 and represented in Figure 2. All the formulations exhibited slow and controlled release upto 8 hours. The percent drug release was found to be in the range of $32.8 \pm 0.43 \%$ to $50.5 \pm 0.60 \%$. The $\mathrm{F} 6$ formulation showed the highest percent drug release when compared to other formulations.

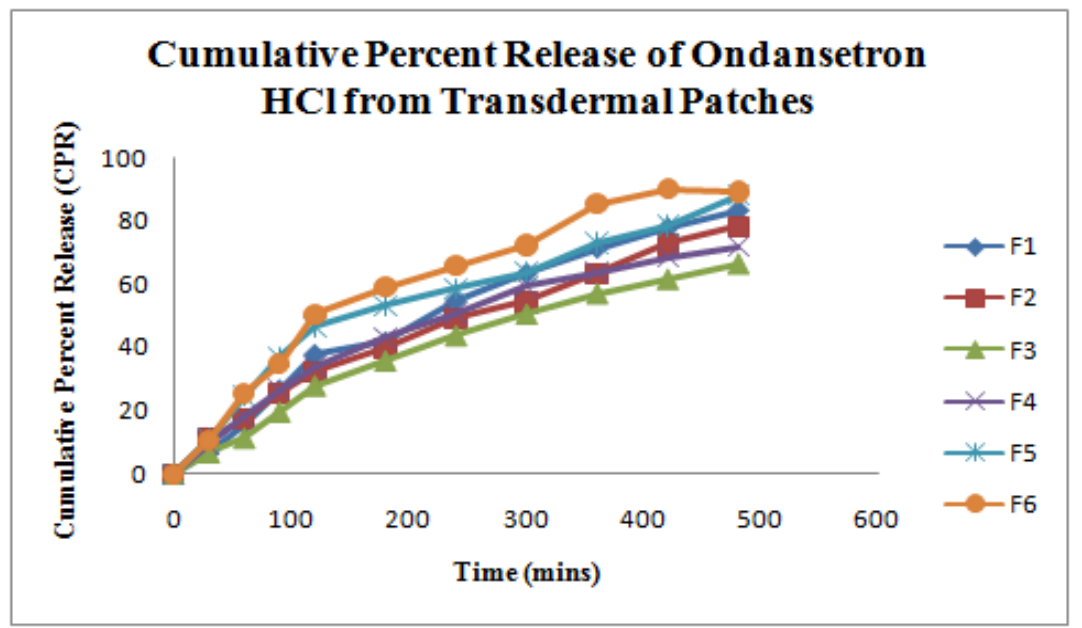

Figure 2: Percent Cumulative Release profiles of Ondansetron Hydrochloride transdermal patches in phosphate buffer solution of $\mathrm{pH} 7.4$ $($ Mean \pm Standard Deviation, $n=3)$

\section{c. In-vitro drug release Kinetics}

In-vitro drug release of Ondansetron $\mathrm{HCl}$ from all the prepared transdermal patches was found to be concentration independent and slow during duration of release study. The drug release kinetics was studied for zero order, first order and Higuchi Model. The correlation coefficient (r) values in the analysis of release data $(\mathrm{K})$ of all formulations for each order are given in Table 3 and Figure 3, (a) zero order, (b) first order and (c) Higuchi's model kinetics, is shown. From the results, it is observed that drug release from all formulations followed zero order kinetics.

Table 3: Drug Release Kinetics of Ondansetron Hydrochloride transdermal patches

\begin{tabular}{|c|c|c|c|c|c|c|}
\hline \multirow{2}{*}{ Code } & \multicolumn{2}{|l|}{ Zero order } & \multicolumn{2}{l|}{ First order } & \multicolumn{2}{l|}{ Higuchi Model } \\
\cline { 2 - 7 } & $\mathbf{r}^{\mathbf{2}}$ & $\mathbf{K}$ & $\mathbf{r}^{\mathbf{2}}$ & $\mathbf{K}$ & $\mathbf{r}^{\mathbf{2}}$ & $\mathbf{K}$ \\
\hline F1 & 0.979 & 0.176 & 0.791 & 0.075 & 0.960 & 14.88 \\
\hline F2 & 0.987 & 0.115 & 0.786 & 0.075 & 0.911 & 13.77 \\
\hline F3 & 0.990 & 0.182 & 0.821 & 0.069 & 0.962 & 14.20 \\
\hline F4 & 0.939 & 0.102 & 0.764 & 0.060 & 0.923 & 12.91 \\
\hline F5 & 0.972 & 0.083 & 0.792 & 0.049 & 0.884 & 9.202 \\
\hline F6 & 0.996 & 0.129 & 0.810 & 0.087 & 0.867 & 14.09 \\
\hline
\end{tabular}




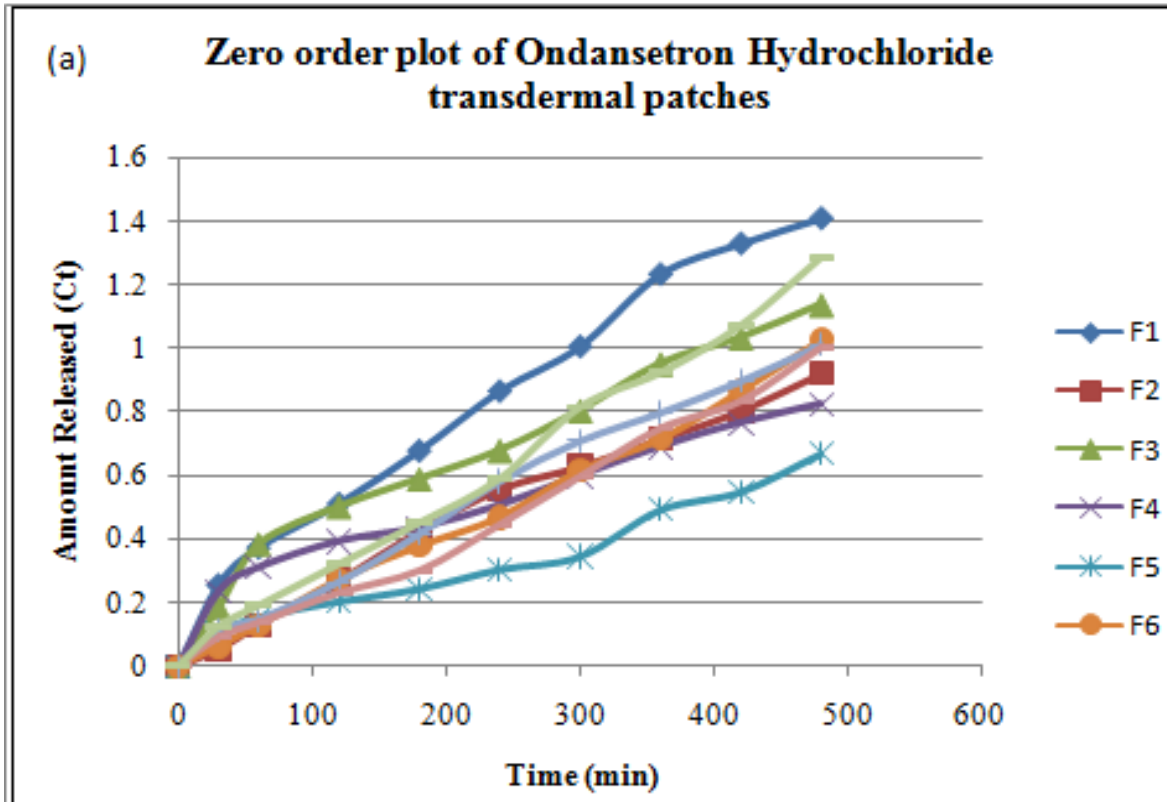

(b) First order plot of Ondansetron Hydrochloride transdermal patches

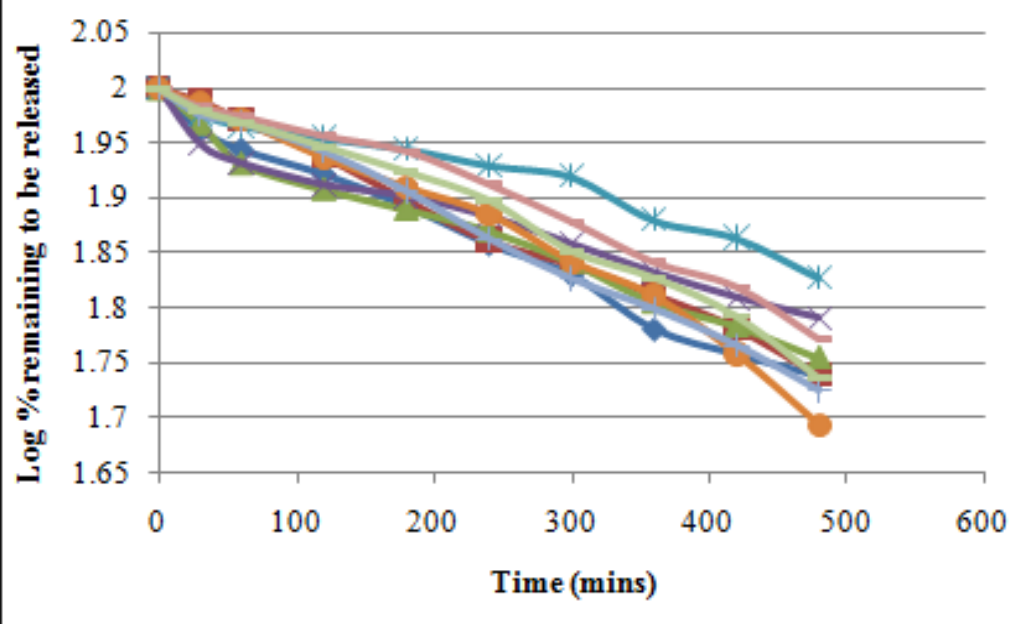

(c) Higuchi Comparison plot of Ondansetron Hydrochloride transdermal patches

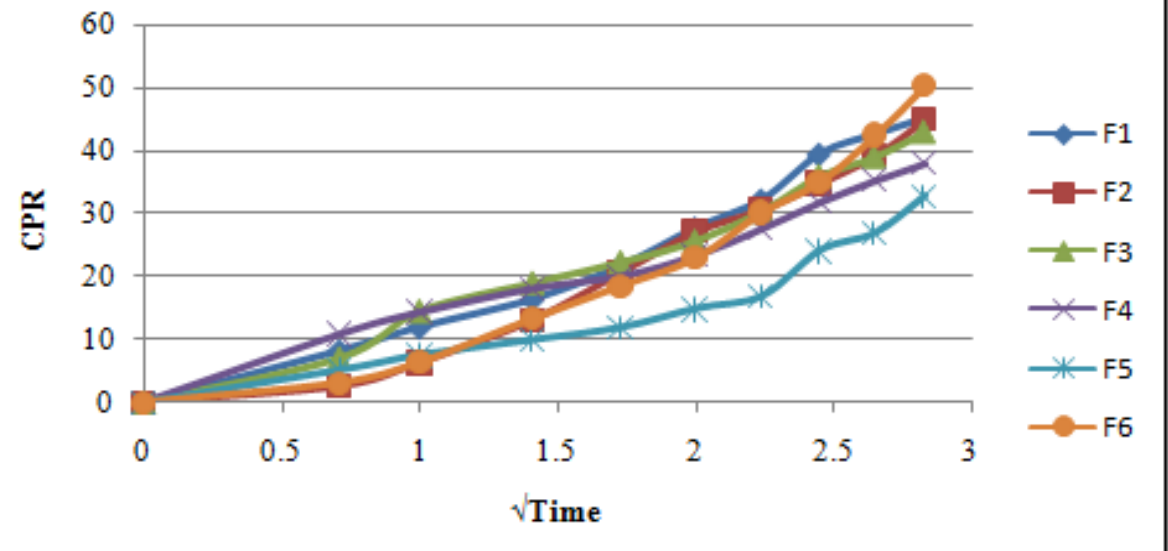

Figure 3: Representation of (a) Zero order kinetics, (b) First order kinetics, (c) Higuchi's model release kinetics of all Ondansetron $\mathrm{HCl}$ transdermal Patches 


\section{d. Drug- Excipient Interaction study by FT-IR Spectrometry}

FTIR spectra are important record which gives sufficient information about the structure of a compound. Unlike UV spectrum which comprises of relatively few peaks, this technique provides a spectrum containing a large number of absorption bands from which structural information are revealed. FTIR spectra of the pure drug were obtained using FTIR spectrometer (FTIR-8400S spectrophotometer, Shimadzu, Japan). The interpretation of FTIR spectra of drug and blend is shown in Table 4.

Table 4: Interpretation of FTIR spectra of Ondansetron Hydrochloride and blend

\begin{tabular}{|c|c|c|c|}
\hline S. no. & Functional group & $\begin{array}{c}\text { Observed frequency } \\
\left(\mathbf{c m}^{-\mathbf{1}}\right) \text { Pure Sample }\end{array}$ & $\begin{array}{c}\text { Observed frequency } \\
\left(\mathbf{c m}^{-\mathbf{1}} \mathbf{)} \text { Blend }\right.\end{array}$ \\
\hline 1. & $\mathrm{C}=\mathrm{O}, \mathrm{C}=\mathrm{N}$ in six membered ring & 1638 & 1524 \\
\hline 2. & $\mathrm{H}_{2} \mathrm{O}$ & 3410 & 3289 \\
\hline 3. & $\mathrm{C}-\mathrm{C}$ ring vibration & 1526 & 1501 \\
\hline 4. & $\mathrm{CH}_{3}$ & 1461 & 1397 \\
\hline 5. & O distributed Benzene & 781 & 674 \\
\hline
\end{tabular}

\section{e. Stability Studies}

A stability studies were performed for three months at $40 \pm 2^{\circ} \mathrm{C}$ and $75 \pm 5 \% \mathrm{RH}$. After three months storage, the formulation (F3) was checked for drug content and percent drug release (shown in Table 5). The similarity index of F3 percent drug release profiles when compared before and after storage was found to be 85.91 . The result from paired t-test $(\mathrm{P}<0.05)$ revealed that there is no significance difference in drug content and percent drug release values before and after storage.

Table 5: Stability studies of F3 formulation before and after 3 months

\begin{tabular}{|c|c|c|}
\hline $\begin{array}{c}\text { Time (Hrs) } \\
\text { CPR (\%) }\end{array}$ & Before Storage & $\begin{array}{c}\text { After 3 Months } \\
\text { storage }\end{array}$ \\
\hline 0 & 0 & 0 \\
\hline 1 & $6.8 \pm 1.7$ & $5.4 \pm 1.28$ \\
\hline 2 & $11.3 \pm 2.2$ & $12.6 \pm 1.13$ \\
\hline 3 & $19.5 \pm 1.62$ & $20.8 \pm 1.65$ \\
\hline 4 & $27.8 \pm 2.61$ & $25.2 \pm 2.16$ \\
\hline 5 & $35.7 \pm 2.4$ & $33.8 \pm 1.8$ \\
\hline 6 & $43.6 \pm 1.17$ & $42.9 \pm 1.9$ \\
\hline 7 & $50.4 \pm 1.53$ & $51.3 \pm 2.2$ \\
\hline 8 & $61.3 \pm 0.98$ & $59.4 \pm 1.9$ \\
\hline 9 & $66.2 \pm 1.3$ & $64.8 \pm 2.3$ \\
\hline Drug Content (\%) & $99.31 \pm 0.24$ & $98.12 \pm 0.32$ \\
\hline
\end{tabular}

*(Mean=Standard Deviation, $\mathrm{n}=3$ )

\section{Discussion}

The present work focuses on the development of transdermal patches containing Ondansetron $\mathrm{HCl}$ by solvent casting method using combination of hydrophilic and hydrophobic polymers. The prepared patched were subjected to various evaluation parameters. Standard curve of pure drug was prepared using phosphate buffer $\mathrm{pH} 7.4$ at $310 \mathrm{~nm}$ by UV-VIS spectrophotometer. Results of physical characterization revealed uniformity in all formulations in terms of thickness, weight variation and drug content whereas folding endurance observation represented formulations flexibility and integrity with general skin folding. The folding endurance was found to be highest in formulation F3, containing combination of PVA, EC and PVP in the ratio of 1:1:2. The moisture content (\%) and Moisture uptake (\%) of all formulations were found in acceptable limits i.e. below 5\% (18). The low moisture content showed the more stability of prepared formulations during storage with respect to reduced brittleness and microbial contamination. The hydration of polymers is important parameter as concerned with the regulation of drug release mechanism from release matrix (controlled/sustained). From the film evaluation, the values of moisture uptake and \% moisture content of all formulations were in the acceptable range. The study of hydration of polymers is an important finding that regulates the drug release from controlled/sustained 
release matrix. In-vitro drug release study showed that F3 was found to have more controlled release pattern than other formulations. The controlled drug release involves the diffusion mechanism as polymer matrix restricts the movement of drug molecules due to its three dimensional network. The drug release in all formulations followed zero-order kinetics that represented the release in concentration independent manner. The FT-IR interpretations of pure and blend (drug + polymers) explained no such significant interactions between them. Results from stability study of $\mathrm{F} 3$ revealed no significant change $(\mathrm{P}<0.05)$ in drug content and percent drug release before and after 3 months storage. In addition to that, the value of similarity index was found to be above $50 \%$ which represents the similarity between release profiles before and after storage (31).

\section{Conclusion}

In the present study, an effort was made to provide transdermal delivery of Ondansetron $\mathrm{HCl}$ with combination of hydrophilic and hydrophobic polymers. The transdermal patch was prepared using solvent casting method using polymers such as PVA, EC, PVP and HPMC in different ratios and eugenol as penetration enhancer. Smooth surfaced, thin and transparent matrix patches were obtained and thickness of all the formulations remained almost similar with low SD values. Physical characterizations of patches were also done and the results found within limits. The in-vitro release study showed that all the formulations exhibited uniform and diffusion-controlled release and followed zero order kinetics. Based on combined results from physical parameters and in-vitro percent drug release and release kinetics, F3 showed the optimum performance. Stabilities studies was conducted for F3 formulations and found stable before and after the storage at $40 \pm 2^{\circ} \mathrm{C}$ and $75 \pm 5 \%$ RH. From the results, it can be concluded that ondansetron $\mathrm{HCl}$, drug with shorter half life and undergoes first pass metabolism, is a suitable candidate for transdermal delivery system. In addition to that, Ondansetron $\mathrm{HCl}$ is considered to be safe in pregnant women and thus prescribed by the medical practitioner in the early stages of pregnancy and also to those patients with hyperemesis gravidarum condition. Hence, transdermal delivery of Ondansetron $\mathrm{HCl}$ will benefit more in the patients facing problems with oral delivery. Besides, it offers a proper way to manage hyperemesis gravidarum condition leading to more patient compliance. Further, this study open up the scope of pharmacokinetic studies and controlled clinical studies on humans in future.

\section{Acknowledgements}

The authors acknowledge Lupin Laboratory Park, Aurangabad, India for gift sample. The authors also thankful to the Department of Pharmaceutical Sciences, SIHAS (SHUATS), Prayagraj, UP, India for providing facilities to support research.

\section{Conflict of Interest}

There is no conflict of interest among authors.

\section{Declaration}

The research work was carried out by Snigdha Bhardwaj, Ph.D Scholar (First and corresponding author) under the kind guidance of Dr. Sonam Bhatia, Assistant Professor (Co-author). We confirmed that the manuscript has been read and approved by all named authors. The content of manuscript have not been published before or submitted elsewhere for publication.

\section{REFERENCES}

[1] Misra, A.N. 1997. Controlled and Novel Drug Delivery. In: Jain NK, editors. Transdermal Drug Delivery. New Delhi, India: CBS Publisher and Distributor, pp. 100-101.

[2] Knutson, K., Krill, S.L., Lambert, W.J. and Higuchi, W.I. 1987. Physicochemical aspects of transdermal permeation. J. Control. Release 6, 59-74.

[3] Rajabalaya, R., Chen, D.S., David, S.R.N. 2013. Development of transdermal ondansetron hydrochloride for the treatment of chemotherapy-Induced nausea and vomiting. Trop. J. Pharm. Res. 12, 279-285.

[4] Verberg, M.F., Gillot, D.J., AI Fardan, N., Grudzinskas, J.G. 2005. Hyperemesis Gravidarum, a literature review. Hum Reprod Update 11, 527-39.

[5] Aka, N., Atalay, S., Sayharman, S., Kilic, D., Kose, G., Kucukozkan, T. 2006. Ieptin and Ieptin receptor levels in pregnancy women with Hyperemesis Gravidarum. Aust NZI Obstet Gynaecol 46, 247-77.

[6] Hassan, N., Khar, R.K., Ali, M., Ali, J. 2009. Development and evaluation of buccal bioadhesive tablet of an anti-emetic agent ondansetron. AAPS Pharm Sci Tech. 10, 1085-1092.

[7] Ahad, A., Aqil, M., Kohli, K., Sultana, Y., Mujeeb, M., Ali, A. 2010. Transdermal drug delivery: the inherent challenges and technologies advancements, Transdermal drug delivery. Asian J. Pharm. Sci. 5, 276-288.

[8] Salem, I.I., Lopez, J.M.R., Galan, A.C. 2001. Ondansetron hydrochloride. In: Brittan HG, editor. Analytical Profiles of Drug Substances and Excipients. San Diego, Calif, USA: Academic Press, pp. 301-339.

[9] Mittal, A., Sara, U., Ali, A. 2009. Formulation and evaluation of monolithic matrix polymer films for transdermal delivery of nitrendipine. Acta Pharmaceutica. 59, 383-393.

[10] Barry, B.W. 2001. Novel mechanisms and devices to enable successful transdermal drug delivery. Eur. J. Pharm. Sci. 14, 101-114.

[11] Moser, K., Kriwet, K., Naik, A., Kalia, Y.N., Guy, R.H. 2001. Passive skin penetration enhancement and its quantification in vitro. Eur. J. Pharm. Biopharm. 52, 103-112.

[12] Chien, Y.W. 1987. Transdermal therapeutic system. In: Robinson JR, Lee VHL. Controlled Drug Delivery Fundamentals and Applications. 2nd ed. New York: Marcel Dekker, Inc., pp. 524-552.

[13] Keith, A.D. 1983. Polymer matrix consideration for transdermal devices. Drug Dev. Ind. Pharm. 9, 605-625. 
[14] Mohd, F. Bontha, L.S., Bontha, V.K., Vemula S.K. 2017. Formulation and evaluation of transdermal films of ondansetron hydrochloride. MOJ Bioequiv Availab. 3, 86-92.

[15] Patel, R.P., Patel, G., Baria, A. 2009. Formulation and evaluation of transdermal patch of aceclofenac. Int. J. Drug Deliv. 1, 41-51.

[16] Patra, S., Choudhury, A.A., Kar, R.K., Barik, B.B. 2007. Spectrophotometric method for ondansetron hydrochloride. Indian J. Pharm. Sci. $69,840-841$

[17] Kumar, S.S., Behury, B., Sachinkumar, P. 2013. Formulation and Evaluation of Transdermal Patch of Stavudine. Dhaka Univ. J. Pharm. Sci. 12, 63-69.

[18] Fathima, F., Kumar, V.B., Rudrangi, S.R.S., Vemula, S.K, Garrepally, P., Chilukula, S., Rudrangi, S. 2011. Formulation and evaluation of matrix-type transdermal delivery system of ondansetron hydrochloride using solvent casting technique. Research $\mathrm{J}$ Pharm and Tech. 4, 806-814.

[19] Garala, K.C., Shinde, A.J., Shah, P.H. 2009. Formulation and in-vitro characterization of monolithic matrix transdermal systems using HPMC/Eudragit S 100 polymer blends. Int. J. Pharm. Pharm. Sci. 1, 108-120.

[20] Keleb, E., Sharma, R., Mosa, E.B., Zaljahwi, A.Z. 2010. Transdermal drug delivery system- design and evaluation. IJAPS. 1, $201-211$.

[21] Kumar, J.A., Pullakandam, N., Prabu, S.L., Gopal, V. 2010. Transdermal drug delivery system: an overview. Int. J. Pharm. Sci. Rev. Res. 3, 49-54.

[22] Shivaraj, A., Selvam, R.P., Mani, T.T., Sivakumar, T. 2010. Design and evaluation of transdermal drug delivery of ketotifen fumarate. Int. J. Pharm. Biomed. Res. 1, 42-47.

[23] Lec, S.T., Yac, S.H., Kim, S.W., Berner, B. 1991. One way membrane for transdermal drug delivery system. II. System optimization. Int. J. Pharm. 77, 231-237.

[24] Prajapati, S.T., Patel, C.G., Patel, C.N. 2011. Formulation and Evaluation of Transdermal Patch of Repaglinide. ISRN Pharmaceutics. Article ID 651909, 9 pages.

[25] Patel, K.N., Patel, H.K., Patel, V.A. 2012. Formulation and characterization of drug in adhesive transdermal patches of diclofenac acid. Int J Pharm Pharm Sci 4, 296-299.

[26] Higuchi, T. 1963. Mechanism of sustained action mediation, theoretical analysis of rate of release of solid drugs dispersed in solid matrices. J. Pharm. Sci. 52, 1145-1149.

[27] Veerareddy, P.R., Vemula, S.K. 2012. Formulation, evaluation and pharmacokinetics of colon targeted pulsatile system of flurboprofen. J Drug Target. 20, 703-714.

[28] Mehrgan, H., Mortazavi, S.A. 2005. The release behavior and kinetic evaluation of diltiazem hcl from various hydrophilic and plastic based matrices. Iran J Pharm Res. 4, 137-146.

[29] Bhat, R. 2013. Potential Use Of Fourier Transform Infrared Spectroscopy For Identification Of Molds Capable Of Producing Mycotoxins. Int. J. Food Prop. 16, 1819-29.

[30] Mathews, B.R.1999. Regulatory aspects of stability testing in Europe. Drug Dev Ind Pharm. 25, 831-856.

[31] Vemula, S.K., Veerareddy, P.R., Devadasu, V.R. 2015. Pharmacokinetics of colon- specific pH and time-dependent flurbiprofen tablets. Eur J Drug Metab Pharmacokinet. 40, 301-311. 